\title{
PARTITION COEFFICIENTS OF ORGANOCHLORINE PESTICIDES ON SOIL AND ON THE DISSOLVED ORGANIC MATTER IN WATER
}

\author{
J.Y. Ding and S.C. Wu \\ Graduate Institute of Environmental Engineering, National Taiwan University \\ 71 Chou-Shan Road, Taipei, Taiwan, R.O.C. 10770 \\ (Received in Germany 26 July 1994; accepted 4 April 1995)
}

\begin{abstract}
The partition coefficients of organochlorine pesticides (OCPs) between the organic matter of Taichung soil and water $\left(K_{\infty c}\right)$ were evaluated with batch-type experiments. The partition coefficients of OCPs between Aldrich humic acid and water $\left(K_{d o c}\right)$ were estimated with solubility enhancement method as well. In this study, the $K_{\text {ocs }}$ of aldrin, heptachlor, and $p, p^{\prime}$-DDT are greater than their $K_{\mathrm{doc}}$, and the relationship of dieldrin and heptachlor epoxide are opposite. The variations of partition coefficients are discussed. For predicting $K_{d o c}$, a $\log -\log$ regression relationship of $K_{\mathrm{doc}}$ and $K_{\mathrm{ow}}$ is determined.
\end{abstract}

\section{INTRODUCTION}

Hydrophobic organic contaminants were considered moving slowly in the environment, owing to their high trend to associate with soils and sediments. The factors controlling the uptake of hydrophobic organic contaminants by zoil include adsorption and partition. Mingelgrin and Gerstl (1983) considered that the interaction between an organic solute and soil was adsorption, and the linear relationship was only observed at significantly low bulk concentrations. On the contrary, there were some investigations (Karickhoff et al., 1979; Briggs, 1981; Chiou et al., 1983; Wershaw, 1986) indicated that the distribution of nonionic organic solutes between soils/sediments and water was partition. Karickhoff et al. (1979) showed that the sorption isotherms for all the hydrophobic compounds studied were linear over a broad range of aqueous concentration. In addition, the linear partition coefficients were directly related to organic carbon content of the studied sediments. Chiou and Shoup (1985) demonstrated that the soil behaved as a dual sorbent, in which the mineral matter functioned as a conventional solid adsorbent and the organic matter as a partition medium. In aqueous system, owing to the strong ability of water to compete against hydrophobic organic solute for mineral surface, the solute partitioning into the soil organic phase is the primary mechanism of soil uptake (Chiou et al., 1985).

Briggs (1981) indicated that despite the complexity of soil organic matter, $K_{\mathrm{om}}$ for a particular chemical is virtually constant. On the contrary, Gauthier et al. (1987) reported that the magnitude of the $K_{\alpha c}$ values correlated strongly with the characteristics of the humic material. Similarly, Kile and Chiou (1989) showed that the 
magnitude of the partition coefficient $\left(K_{\text {dom }}\right.$ or $K_{\text {doc }}$ ) was a function of the physical properties of the solute and the nature of the dissolved organic matter.

However, recent investigations (Enfield et al., 1989; Magee et al., 1991; Dunnivant et al., 1992; Ding and Wu, 1993) indicated that when there was a significant amount of free-moving dissolved organic matter (DOM) in the system, the transport of hydrophobic organic contaminants would be enhanced. Dissolved organic matter (DOM) or dissolved organic carbon (DOC), including dextran, humic acid, could form a third medium for the hydrophobic organic pollutants to associate with and carry these pollutants in the moving water (Enfield et al., 1989; Magee $e t$ al., 1991; Dunnivant et al., 1992; Ding and Wu ,1993).

The partition coefficient between the dissolved organic matter and water is one of the important parameters in modelling the transport and fate of hydrophobic organic contaminants in the environment. The objective of this study is to evaluate the partition coefficients ( $K_{0 c}$ and $K_{\mathrm{doc}}$ ) of some model compounds as an indicator to quantify the enhancement of these compounds on the transport of trace organic pollutants.

\section{MATERIALS AND METHODS}

Properties of soil. The soil for experiments was sampled from an agricultural research station located at Taichung. Soil was air-dried for 14 days, then ground and sieved. All material passing through the sieve with 2-mm cutoff of particle diameter was retained for experimental use. Soil analyses were performed in duplicate and included $\mathrm{pH}$ (at 1:1 soil/water ratio), organic carbon (Walkley-Black method, in Nelson and Sommers, 1982), and particle-size distribution (pipette method, in Gee and Bauder, 1986). The water content of air dried soil was less than $1 \%$. The characteristics of the soil is shown in Table 1.

Table 1. The characteristics of Taichung soil

\begin{tabular}{ll}
\hline soil pH & 6.8 \\
organic carbon content (\%) & 1.8 \\
solid density $\left(\mathrm{g} / \mathrm{cm}^{3}\right)$ & 2.62 \\
sand $(\%)$ & 25 \\
silt $(\%)$ & 40 \\
clay (\%) & 35 \\
texture & clay loam \\
\hline
\end{tabular}

Chemicals and solvents. Test solutes (aldrin, dieldrin, heptachlor, heptachlor epoxide, and $p, p^{\prime}$-DDT) were analytical standards purchased from commercial sources (Riedel-de Haën, Germany) and were used as received. Organic solvents (methanol, n-hexane, and acetone) were residue analysis grade (Baker, U.S.A.).

Organochlorine pesticides analyses. The stock solution of organochlorine pesticides spiked with hexachlorobenzene (EP grade, Tokyo Chemical Inc., Japan) as the internal standard was analyzed with a gas chromatography (Hewlett Packard, HP5890II, Avondale, PA., U.S.A.) with an electron capture detector (ECD). A DB-608 capillary column $(30 \mathrm{~m} \times 0.32 \mathrm{~mm} \times 0.5 \mu \mathrm{m})$ (J\&W Scientific, Folsom, CA., U.S.A.) was used. Carrier gas was nitrogen at $2.58 \mathrm{~mL} / \mathrm{min}$; makeup gas was nitrogen at $34.5 \mathrm{~mL} / \mathrm{min}$; injector was set splitless; temperature 
programmed as $50^{\circ} \mathrm{C}$ for $1 \mathrm{~min}, 50^{\circ} \mathrm{C} / \mathrm{min}$ to $200^{\circ} \mathrm{C}$ for $3 \mathrm{~min}, 5^{\circ} \mathrm{C} / \mathrm{min}$ to $250^{\circ} \mathrm{C}$ for $5 \mathrm{~min}, 8^{\circ} \mathrm{C} / \mathrm{min}$ to $270^{\circ} \mathrm{C}$ for 1 $\mathrm{min}$; injector temperature was $250^{\circ} \mathrm{C}$; detector temperature was $300^{\circ} \mathrm{C}$ (total run time $25 \mathrm{~min}$ ).

Evaluation of $K_{\mathbf{o c}}$. The partition coefficients of the solutes of interest between soil organic matter and water were evaluated with batch experiments. A liter of Milli-Q water (Millipore Corp., Bedford, MA., U.S.A.) in a 2liter cylindrical glass bottle with glass stopper was added 10 grams of air dried soil. Test solutes (aldrin, dieldrin, heptachlor, heptachlor epoxide, and $p, p^{\prime}$-DDT) were dissolved in methanol, and spiked into the suspended solution. The volume fraction of methanol was only $1 \times 10^{-5}$. The spiked amounts of aldrin, dieldrin, heptachlor, heptachlor epoxide, and $p, p^{\prime}$-DDT were $3.81,0.36,3.27,4.41$, and $2.00 \mu \mathrm{g}$, respectively. After that, the bottle was shaken at $25^{\circ} \mathrm{C}$ for 60 hours. It had been tested that the equilibrium states were achieved. Finally, the soil solution was centrifuged at 10500g (Hettich-Zentrifugen Universal 30F, Germany) with Tetlon centrifuge tubes with Teflon caps (Nalge Company, Rochester, NY., U.S.A.) for $1 \mathrm{~h}$ to separate the solid and liquid phases. The organic carbon content of liquid phase was measured with TOC analyzer (OI Company model 700, College Station, TX., U.S.A.) A $900 \mathrm{~mL}$ of liquid phase was extracted for $20 \mathrm{~min}$ with $300 \mathrm{~mL}$ of $\mathrm{n}$-hexane in separating funnel. All solid phase was placed in the extraction thimble (Whatman, England) and extracted for $24 \mathrm{~h}$ with $300 \mathrm{~mL}$ of $1: 1 \mathrm{n}$ hexane/acetone mixed solvent. Each used vessel (glass bottle, Teflon centrifuge tubes, separating funnel and so on) was washed with $10 \mathrm{~mL}$ n-hexane to remove the solutes adsorbed. Each wash was mixed as a sample. The resultant extracts were concentrated to about $3 \mathrm{~mL}$ with a rotary evaporative concentrator and cleaned on a $1-\mathrm{g}$ Florisil column (J\&W Scientific, Folsom, CA., U.S.A.).

Evaluation of $\boldsymbol{K}_{\mathrm{duc}}$. The partition coefficients of solutes between Aldrich humic acid and water $\left(K_{\mathrm{doc}}\right)$ were estimated with water solubility enhancement method which has been used by Chiou et al.(1986). Aldrich humic acid sodium salt (Aldrich Chemical Company, Milwaukee, WI., U.S.A.) was dissolved in Milli-Q water, and centrifuged at $5150 \mathrm{~g}$ for 15 minutes. The centrifuged solution was diluted with Milli-Q water to different concentrations which were measured with TOC analyzer. $20 \mathrm{~mL}$ solutions were placed in $50-\mathrm{mL}$ Teflon centrifuge tubes, and either aldrin, dieldrin, heptachlor, heptachlor epoxide, or $p, p^{\prime}$-DDT was added to each tube in an amount slightly more than required to saturate the solution. Duplicate samples were prepared for each Aldrich humic acid concentration; they were then equilibrated on a reciprocating shaker for $48 \mathrm{~h}$ at $25^{\circ} \mathrm{C}$. The samples were subsequently centrifuged at $5150 \mathrm{~g}$ for $30 \mathrm{~min}$ to separate the undissolved solute. Solute particles adhering to the walls above the liquid level were carefully removed with tissue paper; the meniscus was aspirated to remove any particles on the surface. This centrifugation/cleaning procedure was repeated once more. A $5 \mathrm{~mL}$ sample of the supernatant was withdrawn and extracted for $30 \mathrm{~min}$ with $5 \mathrm{~mL}$ of $\mathrm{n}$-hexane. The samples were gently reduced under nitrogen to about $1 \mathrm{~mL}$ and cleaned on a $1-\mathrm{g}$ Florisil column

\section{RESULTS AND DISCUSSION}

Partition coefficient between soil and water. Backhus and Gschwend (1990) did not believe that low levels of methanol ( $5 \times 10^{-3}$ volume fraction) would affect PAH aqueous activity enough to cause observable effects on PAH sorption by organic carbon. Similarly, the volume fraction of methanol in this study was only $1 \times 10^{-5}$. We believed that it would not affect the partition of solutes between organic carbon and water. In addition, the organic carbon concentration of the liquid phase was measured as $0.78 \mathrm{mg}-\mathrm{C} / \mathrm{L}$. Chiou et al. (1986) reported that the $\log K_{0 c}$ of bulk organic carbon is 6-8 times more efficient than the soil fulvic acid extracts. These artificial water 
soluble organic carbon in liquid phase may be more hydrophilic than fulvic acid extracted from soil. For relatively hydrophobic solutes, the partition coefficients between soil bulk organic carbon and water may be roughly 10 times more than the partition coefficients between the released water soluble organic carbon and water. Such a low concentration of organic carbon in liquid phase will reduce the partition coefficients less than $4 \%$, and its effect may be neglected.

$p, p^{\prime}$-DDD and $p, p^{\prime}-\mathrm{DDE}$ were absent in the spiked solution, but they were found in batch experiments. It indicated that a part of $p, p^{\prime}$-DDT might be transferred to $p, p^{\prime}$-DDD and $p, p^{\prime}$-DDE in the soil/water system in this study. Therefore, we expressed the summation of $p, p^{\prime}-\mathrm{DDE}, p, p^{\prime}-\mathrm{DDD}$, and $p, p^{\prime}$-DDT as the total DDT. The mass adsorbed on all vessel (either glass or Teflon) walls was less than $1 \%$ of the total spiked mass (data not shown). The percentage of the recovery of aldrin, dieldrin, heptachlor, heptachlor epoxide, and total DDT were $89.8,103.9,72.8,90.7$, and 110.0 , respectively. The partition coefficients of organochlorine pesticides between soil and water $\left(K_{\mathrm{ps}}\right)$ were evaluated, and $K_{\mathrm{ocs}}$ were normalized from $K_{\mathrm{ps}}$ with organic carbon fraction of soil (1.8 $\%)($ Table 2).

Table 2. The results of batch experiments and the partition coefficients of test solutes

\begin{tabular}{lccrr}
\hline Compound & $\begin{array}{c}\text { Concentration of } \\
\text { OCP on soil } \\
(\mu \mathrm{g} / \mathrm{g} \text {-soil })\end{array}$ & $\begin{array}{c}\text { Concentration of } \\
\text { OCP in water } \\
(\mu \mathrm{g} / \mathrm{L} \text {-water })\end{array}$ & $\begin{array}{c}K_{\mathrm{p}} \\
(\mathrm{mL} / \mathrm{g})\end{array}$ & $\begin{array}{c}K_{\mathbf{0 c}} \\
(\mathrm{mL} / \mathrm{g})\end{array}$ \\
\hline aldrin & 0.3338 & 0.0768 & 4350 & 241500 \\
dieldrin & 0.0339 & 0.0347 & 980 & 54300 \\
heptachlor & 0.2178 & 0.1521 & 1430 & 79600 \\
heptachlor epoxide & 0.3142 & 0.8446 & 370 & 20700 \\
$p, p^{\prime}$-DDT & 0.1942 & 0.0225 & 8640 & 479500 \\
$p, p^{\prime}$-DDD & 0.0042 & 0.0018 & 2350 & 130600 \\
$p, p^{\prime}$-DDE & 0.0164 & 0.0347 & 470 & 26300 \\
\hline
\end{tabular}

Solubility enhancement experiments. Dissolved organic matter may enhance water solubility of hydrophobic solutes (Carter and Suffet, 1982; Landrum et al., 1984; Gschwend and Wu, 1985; McCarthy and Jimenze, 1985; Chiou et al., 1986). If one assumes that a partition-like interaction with dissolved organic carbon is responsible for solute water solubility enhancement, the magnitude of this effect for an organic solute with respect to a specific DOC can be expressed as (Chiou et al., 1986)

$$
S_{w}^{*}=S_{w}\left(1+X K_{d o c}\right)
$$

where $S_{\mathrm{w}^{*}}$ is the apparent solute solubility in water containing DOC (as cosolute) at concentration $X$ (in gram per milliliter of water), $S_{\mathrm{w}}$ is the solubility in pure water, and $K_{\mathrm{doc}}$ is the corresponding organic-carbon-based partition coefficient. Partition coefficients $\left(K_{\mathrm{doc}}\right)$ for the pairs of Aldrich humic acid and solutes were determined (according to equation 1) by plotting the apparent solubility $\left(S_{w^{*}}\right)$ against the concentration of Aldrich humic acid. The slope gives $S_{\mathrm{w}} K_{\mathrm{doc}}$, and the intercept gives $S_{\mathrm{w}}$. The results are shown in Figure 1.

The values of $\log K_{\mathrm{doc}}$ of aldrin, dieldrin, heptachlor, heptachlor epoxide, and $p, p^{\prime}$-DDT are 5.05, 4.89, 4.48, 4.46 , and 5.53, respectively. The value of $\log K_{\mathrm{doc}}$ of $p, p^{\prime}$-DDT based on Aldrich humic acid in this study (5.53) is similar to the results of 5.44 measured from reverse-phase separation technique (Landrum et al., 1984), 5.61 
evaluated from equilibrium dialysis technique (Carter and Suffet, 1982), and 5.56 estimated from water solubility enhancement method (Chiou et al., 1987).
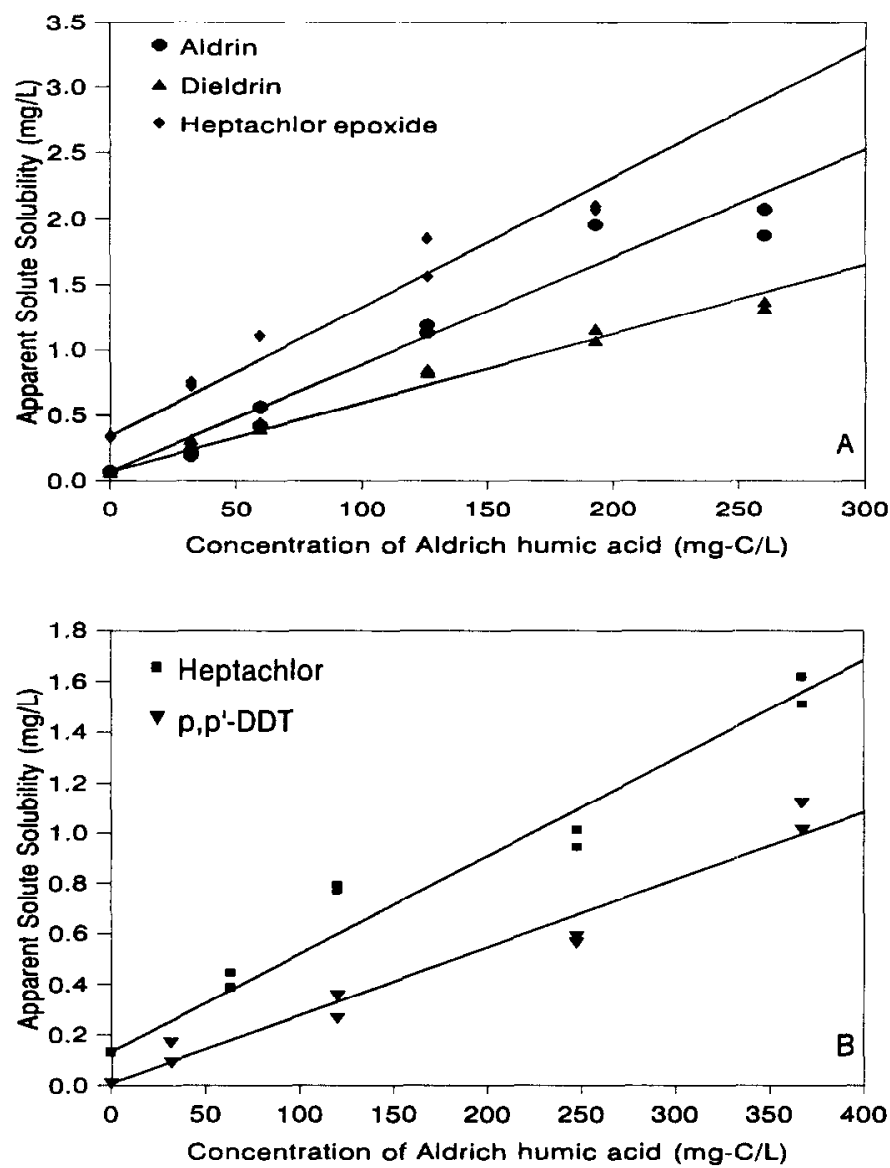

Figure 1. Dependence of the apparent water solubility of aldrin, dieldrin, heptachlor epoxide (A), heptachlor, and $p, p^{\prime}$-DDT (B) on the concentration of Aldrich humic acid.

Variations of partition coefficients. Comparison of $\log K_{\mathrm{oc}}, \log K_{\mathrm{doc}}$ and $\log K_{\mathrm{ow}}$ values of test solutes is shown in Table 3. The value of $\log K_{\mathrm{oc}}$ is less than the value of $\log K_{0 w}$ of each test solute. Chiou et al. (1983) indicated that soil organic matter is inferior to octanol as partition phase for relatively nonpolar organic compounds and that is quite reasonable as the organic matter is generally more polar than octanol. Similarly, it is the explanation for the lower value of $\log K_{\text {doc }}$ than the value of $\log K_{\text {ow }}$ of each test solute.

The $K_{\mathrm{oc}} \mathrm{S}$ of aldrin, heptachlor, and $p, p^{\prime}$-DDT are greater than their $K_{\mathrm{docs}}$, and the relationships for dieldrin and for heptachlor epoxide are the opposite. The sources and the nature of the soil bulk organic carbon of Taichung soil and the dissolved Aldrich humic acid are different. The molecular polarities of dieldrin and heptachlor epoxide are greater than those of aldrin and heptachlor. We consider that this is one of the sakes for the variations of partition coefficients of the model solutes in this study. 
Table 3. The comparison of partition coefficients of test solutes

\begin{tabular}{llcc}
\hline Compound & $\log K_{\mathrm{oc}}$ & $\log K_{\text {doc }}$ & $\log K_{\text {ow }}$ \\
\hline aldrin & 5.38 & 5.05 & $5.52^{\mathrm{a}}$ \\
dieldrin & 4.73 & 4.89 & $5.48^{\mathrm{b}}$ \\
heptachlor & 4.90 & 4.48 & $5.44^{\mathrm{b}}$ \\
heptachlor epoxide & 4.32 & 4.46 & $5.40^{\mathrm{b}}$ \\
$p, p^{\prime}$-DDT & 5.68 & 5.53 & $6.36^{\mathrm{c}}$ \\
\multicolumn{2}{c}{${ }^{\mathrm{a}}$ cited from Garten and Trabalka (1983), ${ }^{\mathrm{b}}$ cited from Mackay (1982), } \\
${ }^{\mathrm{c}}$ cited from Chiou et al. (1982)
\end{tabular}

When the nature of the dissolved organic matter released from the soil/sediment bulk organic matter is similar to that of the soil/sediment bulk organic matter, the ratios of $K_{\mathrm{dod}} / K_{\mathrm{oc}}$ of solutes will be close to 1 . If the dissolved organic matter is more hydrophilic than the soil/sediment bulk organic matter, they tend to escape from soil/sediment particles to the aqueous phase, and the ratios of $K_{\text {dod }} / K_{0 \mathrm{cc}}$ of these solutes will be less than 1. The $K_{\text {docs }}$ to nonsettling colloids were 0.5-1 times the $K_{0 c}$ s to sediments of the Lake Superior for PCB congeners (Gschwend and $\mathrm{Wu}, 1985$; Baker et al., 1986). When the sources and nature of the dissolved organic matter and soil/sediment organic matter are different, the ratios of $K_{\text {doc }} / K_{\text {oc }}$ of solutes will have a broad range. For 2,4,4'PCB, the value of $\log K_{\text {OC }}$ was measured as 4.38 (Chiou et al., 1983), and the values of $\log K_{\text {doc }}$ were measured as 3.53-4.83 (Chiou et al., 1987); the ratios of $K_{\mathrm{dod}} K_{\mathrm{oc}}$ were $0.14-2.88$. For 2,2',5,5'-PCB, the values of $\log K_{\mathrm{oc}}$ were measured as 5.35 (Baker $e t$ al., 1986), and the values of $\log K_{\text {doc }}$ were measured as 3.23-5.68 (Landrum $e t$ al., 1984); the ratios of $K_{\text {dod }} / K_{\text {oc }}$ were 0.008-2.14. For $p, p^{\prime}$-DDT, the values of $\log K_{\text {oc }}$ were measured as 4.97-5.63 (Vinten et al., 1983; Gerstl, 1990), and the values of $\log K_{\text {doc }}$ were measured as 4.23-5.74 (Chiou et al., 1987; Landrum et al., 1984; Carter and Suffet, 1982); the ratios of $K_{\mathrm{doc}} / K_{\mathrm{oc}}$ were 0.04-5.9.

A $\log$-log regression equation of $K_{\mathrm{doc}}$ and $K_{\mathrm{ow}}$ from this study is determined as:

$$
\log K_{\mathrm{doc}}=0.96 \log K_{\mathrm{ow}}-0.51 \quad\left(\mathrm{n}=5, \mathrm{r}^{2}=0.76\right)
$$

The correlation between $K_{\text {doc }}$ and $K_{\text {ow }}$ of some hydrophobic solutes is shown in Figure 2. The magnitudes of $K_{\text {doc }}$ of a particular solute to the relatively hydrophilic and more hydrophobic DOCs may show about one to two orders of variation. The data collected from the literatures are shown in Figure 2, including some hydrophilic DOCs. For predicting the $K_{\text {docs, }}$ equation 2 will be adaptable for relatively hydrophobic DOCs, however, may have larger error toward overestimation.

\section{CONCLUSIONS}

According to the results in the literatures and this study, in aqueous system, the interactions of hydrophobic organic solutes between soil organic matter and water or dissolved organic matter and water are partition. The variations of the partition coefficients are dependent on the characteristics of the solutes and the sources and nature of the organic carbons. For predicting the $K_{\mathrm{docs}}$, A log-log regression equation of $K_{\text {doc }}$ and $K_{\text {ow }}$ is determined. It is also adaptable for relatively hydrophobic DOCs. 


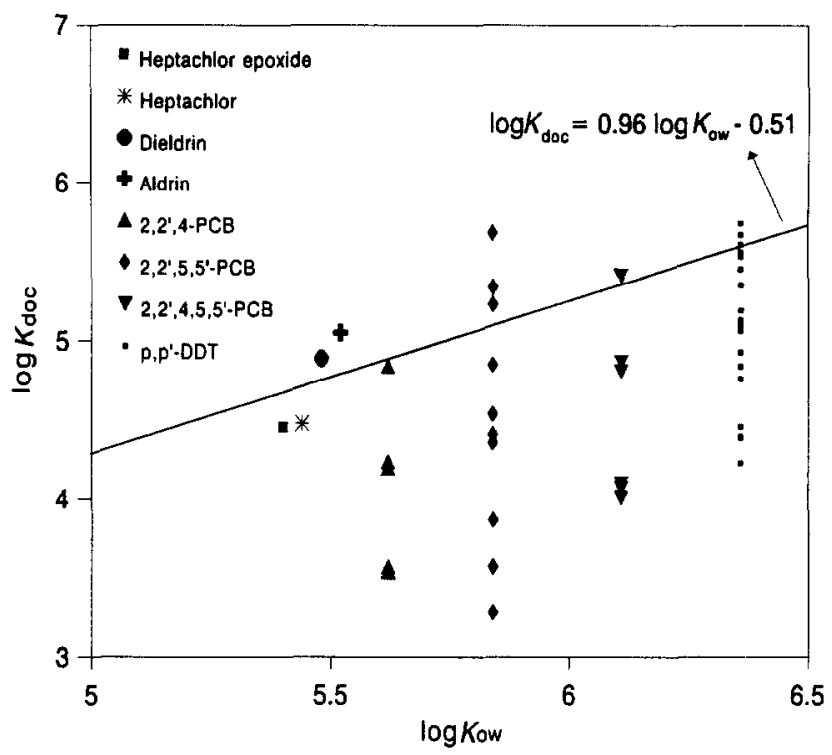

Figure 2. Correlation between $K_{\mathrm{doc}}$ and $K_{\mathrm{ow}}$. The data are cited from Mackay (1982), Garten and Trabalka (1983), Carter and Suffet (1982), Landrum et al. (1984), Chiou et al. (1982, 1986, 1987), and this study.

\section{ACKNOWLEDGMENTS}

The authors express their gratitude to the National Science Council, Taiwan, R.O.C. for its financial support. (Contract No.: NSC82-0421-E-002-033).

\section{REFERENCES}

Backhus, D.A. and Gschwend, P.M., 1990. Environ. Sci. Technol. 24:1214-1223.

Baker, J.E., Capel, P.D. and Eisenreich, S.J., 1986. Environ. Sci. Technol. 20:1136-1143.

Briggs, G.G., 1981. J. Agric. Food Chem. 29:1050-1059.

Carter, C.W. and Suffet, I.H., 1982. Environ. Sci. Technol, 16:735-740.

Chiou, C.T., Schmedding, D.W., and Manes, M., 1982. Environ. Sci. Technol. 16:4-10.

Chiou, C.T., Porter, P.E. and Schmedding, D.W., 1983. Environ. Sci. Technol. 17:227 -231.

Chiou, C.T. and Shoup, T.D., 1985. Environ. Sci. Technol. 19:1196-1200.

Chiou, C.T., Shoup, T.D. and Porter, P.E., 1985. Org. Geochem. 8:9-14.

Chiou, C.T., Malcolm, R.L., Brinton, T.I. and Kile, D.E., 1986. Environ. Sci. Technol. 20:502-508.

Chiou, C.T., Kile, D.E., Brinton, T.I., Malcolm, R.L., Leenheer, J.A. and MacCarthy, P., 1987. Environ. Sci. Technol. 21:1231-1234.

Ding, J.-Y. and Wu, S.-C., 1993. Wat. Sci. Tech. 28:199-208.

Dunnivant, F.M., Jardine, P.M., Taylor, D.L. and McCarthy, J.F., 1992. Environ. Sci. Technol. 26:360-368.

Enfield, C.G., Bengtsson, G. and Lindqvist, R., 1989. Environ. Sci. Technol. 23:1278-1286. 
Garten, C. T. Jr., Trabalka, J. R., 1983. Environ. Sci. Technol. 17:590-595.

Gauthier, T.D., Seitz, W.R. and Grant, C.L., 1987. Environ. Sci. Technol. 21:243-248.

Gee, G.W. and Bauder, J.W., 1986. In Methods of soil analysis. part 1 physical and mineralogical methods. Ed. by

Klute, A. Agronomy monograph no.9 (2nd ed.), America Society of Agronomy, Madison, U.S.A. pp. 383-412.

Gerstl, Z., 1990. J. Contam. Hydrol. 6:357-375.

Gschwend, P.M. and Wu, S.-C., 1985. Environ. Sci. Technol. 19:90-96.

Herbert, B.E., Bertsch, P.M. and Novak, J.M., 1993. Environ. Sci. Technol. 27:398-403.

Karickhoff, S.W., Brown, D.S. and Scott, T.A., 1979. Water Res. 13:241-248.

Kile, D.E. and Chiou, C.T., 1989. In Aquatic humic substances influence on fate and treatment of pollutants. Ed. by Suffet, I.H. and MacCarthy, P. America Chemical Socity, Washington, DC. pp. 131-157.

Landrum, P.F., Nihart, S.R., Eadle, B.J. and Gardner, W.S., 1984. Environ. Sci. Technol. 18:187-192.

Mackay, D., 1982. Environ. Sci. Technol. 16:274-278.

Magee, B.R., Lion L.W. and Lemley, A.T., 1991. Environ. Sci. Technol. 25:323-331.

McCarthy, J.F. and Zachara, J.M., 1989. Environ. Sci. Technol. 23:496-502.

Mingelgrin, U. and Gerstl, Z., 1983. J. Environ. Qual. 12:1-11.

Nelson, D.W. and Sommers, L.E., 1982. In Methods of soil analysis. part 2 chemical and microbiological properties. Ed. by Page, A.L., Miller, R.H. and Keeney, D.R., Agronomy Monograph no. 9 (2nd ed.), America Society of Agronomy, Madison, U.S.A. pp. 539-580.

Vinten, A.J.A., Yaron, B. and Nye, P.H., 1983. J. Agric. Food Chem. 31:662-664.

Wershaw, R.L. 1986. J. Contam. Hydrol. 1:29-45. 